\title{
Analysis on the Differences Between the Private school in China and in Western Countries
}

\author{
Chenyan Wang \\ Business school, University of Surrey, Guildford, Surrey, GU2 7XH, the UK \\ *Corresponding author. Email: cw01158@surrey.ac.uk
}

\begin{abstract}
With the development of the world, parents around the world are more and more strict with their children's education, and their demands are becoming higher and higher. Therefore, there are a lot of private schools around the world, but the private schools in each country have their own characteristics. This paper will explain the differences between China and western countries in running private schools from the perspectives of history, school-running philosophy, fund-raising mode and school-running mode. Then, this paper will explain how China should improve to make Chinese private schools better and have their own uniqueness. This paper collected data by searching online materials and conducting surveys, and the target population was mainly parents and teachers from international schools, thus drew the following conclusions: First, the evaluation of students in China's private schools should be based on their usual scores so as to see the most real level of students. Second, schools should pursue diversity to better develop the potential of students. Third, schools should maintain their own characteristics and formulate their future development path.
\end{abstract}

Keywords: Private schools, China, Western countries, Characteristics, Diversity

\section{INTRODUCTION}

Nowadays, there are many differences between the private school in China and in western countries. And with the development of the world, all countries need more innovative people. They either have the essence of hard work or have high IQ. Therefore, parents pay more attention on the education of children. They want to develop their children's potential and know how their children's performance in the class clearly. Also, in China, people want to send their children to some foreign schools when they grow up, so they need an English environment to study. The private school will provide what they want. For the western countries, they have greater choice and flexibility which means that parents are able to search for private programs that have values that align with their own and they could have a tighter student-parent-teacher relationship. Because the private school do not have such many students, the teacher could have more energy to treat every student. Then, the assessment will discuss the differences between the private school in western countries and China in several dimensions.
This paper will use some surveys about 50 people who are not only the private school's teachers but also the parents. Also, the assessment will use some online references to prove the author's points.

\section{DEVELOPMENT STATUS OF CHINA'S PRIVATE UNIVERSITIES}

On the basis of comparing the differences of higher education between China and foreign countries, it is not difficult to find that private institutions of higher learning in China are in a rather awkward position compared with foreign countries. For one thing, they are limited in the source of students. For another, their scientific research achievements are not outstanding. But some foreign private colleges and universities have become the academic centers of the whole country and even the world. This phenomenon has caused the author's thinking. This paper mainly analyzes and compares the gap between Chinese and foreign private higher education, and tries to achieve some enlightenment from it.

Since 1987, the rise of private colleges and universities in China has broken the traditional education pattern and formed a new form of running 
schools. In the process of continuous development and improvement, private colleges and universities have become an important part of higher education in China, and become the main force of higher education popularization. The development status of China's private colleges and universities can be summarized from the following five aspects: Firstly, the current private colleges and universities mainly rely on the cooperation with social groups, enterprises and institutions, "borrow chicken eggs", mutual benefit, continuous accumulation of funds. A large number of enterprises are the main economic source of private colleges and universities. Secondly, compared with the bloated institutional system of state-owned colleges and universities, the flexible system and simple organization of private colleges and universities are not only conducive to saving unnecessary expenses, but also conducive to clarifying responsibilities and improving work efficiency. Thirdly, in terms of teachers, private colleges and universities hire more experienced professors from famous universities and train young teachers at the same time. With the continuous expansion of the teaching staff, private colleges and universities do not lag behind state-run colleges and universities to a large extent. Fourthly, in terms of teaching design, private colleges and universities generally pay more attention to the teaching and mastering of foreign languages and computer applications. At the same time, students are encouraged to take all kinds of certificates actively to acquire the use of skills. Fifthly, in terms of foreign exchange, many private colleges and universities do not lag behind state-run colleges and universities. Many private colleges and universities also set up overseas study and student exchange programs to meet the needs of more students to study abroad [4].

\section{THE HISTORY OF PRIVATE UNIVERSITIES ABROAD}

As for the historical origin of foreign private universities, different countries have different development processes. Most countries have a longer history, a larger proportion and a higher quality of private higher education than China. At present, the development of foreign private colleges and universities can be summarized in three aspects: First, many developed countries strongly support the development of private colleges and universities. For example, in 1975, the Japanese government promulgated the Private Assistance Act, which expressly stipulated that the government should give financial aid to private universities. Since then, Japan's private colleges and universities have developed by leaps and bounds in terms of number, scale and quality. The federal government of the United States implements tax guidance for non-profit private universities, which means that non-profit universities will receive tax subsidies from the state and state governments in addition to being exempted from taxes. Second, private schools in most countries in the world pay more attention to school quality and the development of characteristic education. Harvard is one of the most famous private universities in the United States. It has given birth to seven American presidents and 37 Nobel Prize winners. It is the cradle of great men. Two thirds of the top decision makers of the Fortune 500 companies in the United States are from Harvard Business School, which has formed a characteristic of Harvard school. Similarly, Yale, Cornell, and MIT are all proud of America's private universities, highlighting the high quality of private education in the United States. Third, the board of trustees should be established. The authority of private universities is called the board of trustees in the United States and the Board of Trustees in Japan. The members are representatives of the sponsoring school, related personnel of government departments, representatives of alumni and teachers, etc. Its job is to decide on the development of the school.

\section{DIFFERENT HISTORY}

The origin of the private schools in China is earlier than other countries. Private education has appeared in China since the founding of the Confucius school. The history of the private higher education in other countries, especially some developed countries such as Japan and the United States, is much shorter than in China.Moreover, the development scale and coverage are also smaller. In China, the private education has existed more than 2000 years, people are all familiar with the private school education. Moreover, for western countries, they only have about 400 years' history of private school education. However, no matter the modern Confucius Institutes in China or the ancient private schools in China, their target groups are usually relatively young children, and they serve as the enlightenment teaching for children. But in western countries, their private school's education is usually higher education. Parents prefer to send their children to private school, because they can have better education, and children can get more academic opportunities which means that private schools can provide their students a multicultural and challenging educational experience. Students can join more activities, international programs, placement courses and other competitions. Students in private school can not feel these various activities. Also, they can have a smaller class size, and teachers can have more energies to look after more kids and have more communication with students' parents. But in China, although the size of public schools is larger than the size of private schools, parents prefer their kids to go to public schools. One of the reasons is that China has nine years of compulsory education. In these nine years, parents do not need to 
pay a lot attention to their children at school. And another reason is that most parents let their children take the college entrance examination rather than study abroad. And public schools will provide a better environment for college entrance examination so public schools are more famous than private schools in China [1].

\section{DIFFERENCES IN SCHOOL'S CONCEPTS}

Table 1. Age-related educational opportunities in China, Australia, the UK and the US [5].

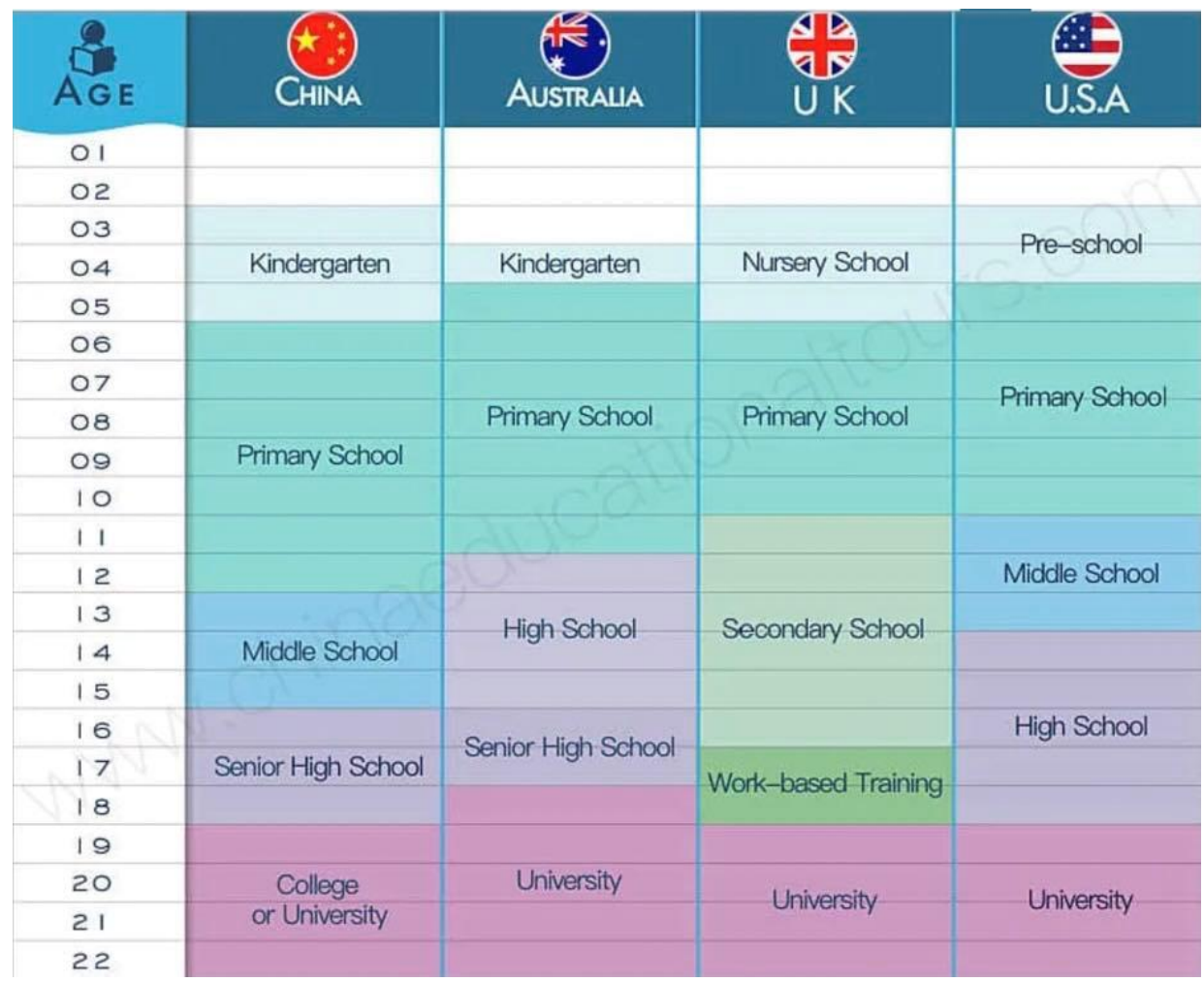

As it can be seen from the table above, age-related educational opportunities are different between China and the other three western countries- Australia, the UK and the USA. The reason why there is a large difference of age-related educational opportunities between China and three western countries is that the schools in western countries are aimed to prepare children and youth to become productive members of society but the schools in China will divide the children into some different levels to help children to choose what they will do in the future. This is the reason why there are some differences between China and western countries. Some colleges and universities in China, including private colleges and universities, are under the control of administrative power and the influence of market economy, and the shadow of the government, enterprises and small society appears, unlike schools. Foreign private colleges and universities focus on academic research and the improvement of teaching quality. Although they are also affected by marketization and the infiltration of government administrative power, they generally do not have administrative rank, and the president is mainly responsible for academic communication. In western countries, the population of western countries is smaller than China, which means that they have less pressure on finding a good job and the system is relatively democracy every person have the right to speak, they could say what they want and what they need. However, in China, the population is too large and most of them are only child, every child has the responsibility to be the hope of their parents and even grandparents for the future, they had great hope to their kids. And in China, people pay more attention on the ability to imitate of children, this is because of the traditional Chinese education philosophy, however, western countries focus on students' innovation ability and independent thinking consciousness [6].

\section{DIFFERENT FINANCING METHODS}

China is a socialist country, while many western countries are capitalist countries. Because of the difference between Chinese and Western systems, the main financing methods of private schools in China and western countries are different [2].

The main financing methods of private colleges and universities in China include students' tuition and miscellaneous fees, enterprise funds, school assets income and social funds. Generally speaking, private colleges and universities in China do not have many financing channels, and the phenomenon of capital shortage often occurs. In contrast, as it can be seen in 
bottom two tables, the first one is finances of Stanford University and the second is annul financial report of Harvard University. In addition to student tuition fees and government donations, foreign private universities receive a major source of income from donations, including donations from corporations, private organizations and social organizations, a large part of which are donated by famous alumni.

Table 2. Fiscal 2014 sources of operating revenue of Stanford University [7]

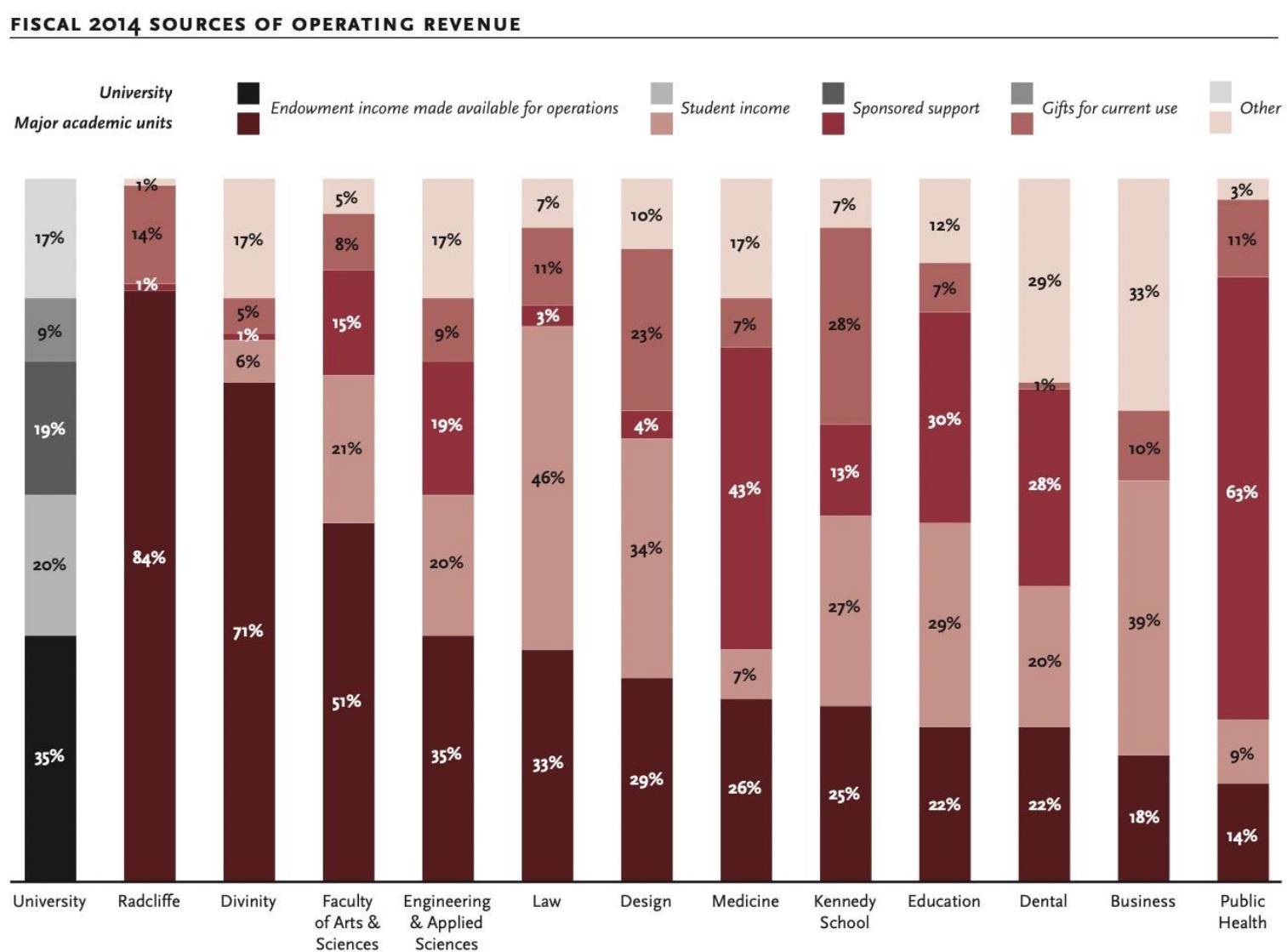

Table 3. Annul financial report of Harvard University [8]

\begin{tabular}{|lc|}
\hline $\begin{array}{l}\text { SOURCES OF FUNDS FOR FY 2014-15 } \\
\text { Sponsored research }\end{array}$ & $18 \%$ \\
\hline Endowment income & $21 \%$ \\
\hline Other investment income & $4 \%$ \\
\hline Student income & $16 \%$ \\
\hline Health care services income & $15 \%$ \\
\hline Expendable gifts and net assets released & $6 \%$ \\
\hline SLAC National Accelerator Laboratory & $8 \%$ \\
\hline Other income & $11 \%$ \\
\hline
\end{tabular}

EXPENDITURES FOR FY 2014-15

\begin{tabular}{|lr|}
\hline Salaries \& benefits & $60 \%$ \\
\hline Operating expenses & $31 \%$ \\
\hline Debt service & $4 \%$ \\
\hline Financial aid & $5 \%$
\end{tabular}




\section{MANAGING DIFFERENT OPERATING MODES}

In China's private colleges and universities, we can see the shadow of enterprise operation to a large extent. The for-profit purpose is too strong, which hampers the development of the schools to a large extent. In contrast, foreign private universities consist of teaching and administration. The board of directors or the board of governors decides school affairs through consultation, and the president is in charge of scientific research and teaching.

\section{THINGS WE CAN STUDY FROM WESTERN COUNTRIES}

\subsection{Based on scientific research}

The promotion of scientific research is the primary task of a school. China's private colleges and universities have obvious shortcomings in this aspect. On the one hand, they are affected by the low quality of students, on the other hand, they are also affected by the teaching system of the school. But the heart of American academia is concentrated in the private institutions that produce the most important research. In Finland, The improvement of scientific research results and teaching quality is what a university should focus on [3].

\subsection{Pursue diversification}

Higher education undertakes the important task of cultivating talents. The diversity of social demands for talents determines the diversity of levels and types of higher education. At present, there are more than 160 private colleges and universities in China that can issue state-recognized graduation certificates, accounting for almost half of the universities in China. Therefore, private colleges and universities must recognize their own position in the national education, according to local conditions, scientific positioning, take a variety of ways to run schools.

\subsection{Adhere to the characteristics, based on adaptability}

For private schools, characteristics are competitiveness. Private colleges and universities in China are in a special environment. If they want to adapt to the current situation in China, they must find a distinctive development path. China's private colleges and universities have great potential for development. When formulating the development strategic goals, we should recognize our own advantages and disadvantages, strengthen the school with characteristics, and establish the school with characteristics.

\section{CONCLUSION}

This article mainly analyzes the current status of domestic and foreign development of private universities from history, educational philosophy and university level, financing, management, operation mode, teachers and so on, and gets the conclusion about how Chinese private school could study from private school in western countries, the private colleges and universities in China should be based on scientific research, the pursuit of diversity and characterization. In the special political and economic environment, out of a road with its own characteristics.

\section{REFERENCES}

[1] Tenney School. 2021. Why I'm a Public School Teacher But a Private School Parent - Tenney School. [online] Available at: https://tenneyschool.com/why-im-a-public-school-t eacher-but-a-private-school-parent/ [Accessed 29 September 2021].

[2] Yun Tsang, C., 2021.The Chinese Financial System vs. the Western Financial System: Differences and Similarities | Herbert Smith Freehills CIBEL Centre. [online] Cibel.unsw.edu.au. Available at: https://www.cibel.unsw.edu.au/blog/chinese-financ ial-system-vs-western-financial-system-differences -and-similarities [Accessed 30 August 2016].

[3] Kate, 2019. New Study Confirms That Private Schools Are No Better Than Public Schools [online] Public School Review. Available at: https://www.publicschoolreview.com/blog/new-stu dy-confirms-that-private-schools-are-no-better-tha n-public-schools> [ Accessed 29 September 2021]

[4] Liu, X., 2018. [online] Available at: https://www.researchgate.net/publication/3276043 65_The_Development_of_Private_Universities_in _Socialist_China [Accessed 29 September 2021].

[5] Wickham, R., 2021.Differences in Education between China and Western Countries. [online] China Educational Tours. Available at: https://www.chinaeducationaltours.com/guide/artic le-differences-in-education-between-china-and-we stern-countries.htm [Accessed 29 September 2021].

[6] Magazine, S. and Hancock, L., 2011. Why Are Finland's Schools Successful?. [online] Smithsonian Magazine. Available at: https://www.smithsonianmag.com/innovation/why- 
are-finlands-schools-successful-49859555/

[Accessed 29 September 2021].

[7] Forward", 6., Home, S., MacGowan, F. and Series, W., 2021.Stanford University. [online] Stanford University. Available at: https://www.stanford.edu [Accessed 29 September 2021].
[8] University, H., 2021.Harvard University. [online] Harvard University. Available at: https://www.harvard.edu [Accessed 29 September 2021]. 